\title{
Serum biochemistry profile in newborn Senepol and crossbred Holstein x Gir calves aged three to five days in Uberlândia, Minas Gerais, Brazil
}

\section{Perfil bioquímico sérico de bezerros neonatos da raça Senepol e mestiços Holandês x Gir de três a cinco dias de idade no município de Uberlândia, MG, Brasil}

\author{
Lara Reis Gomes ${ }^{1 *}$; Renata Dias Rodrigues ${ }^{1}$; Rafael Rocha de Souza ${ }^{1}$; \\ Amanda Bizare²; João Gabriel knychala Faria ${ }^{3}$; Christina Resende Martinss; \\ Ednaldo Carvalho Guimarães ${ }^{5}$; Antonio Vicente Mundim ${ }^{6}$
}

\begin{abstract}
This study aimed to evaluate the physiological variations in the serum biochemical profile of neonate (3-5 days old) Senepol and crossbreed Holstein x Gir calves in Uberlândia, state of Minas Gerais, Brazil, and to compare values between breeds and sexes. In total, 168 healthy Senepol ( $\mathrm{n}=80,28$ females and 52 males) and crossbred Holstein x Gir ( $\mathrm{n}=88,49$ females and 39 males) calves were evaluated. From each animal, approximately $5 \mathrm{~mL}$ of blood was collected by jugular venipuncture into a sterile tube without anticoagulant to obtain serum. Serum concentrations of total protein, albumin, creatinine, urea, total cholesterol, triglycerides, calcium, and phosphorus; and the activities of alanine aminotransferase (ALT), aspartate aminotransferase (AST), alkaline phosphatase, and gamma-glutamyl transferase (GGT) were determined on a automated multichannel analyzer. There were significant differences $(\mathrm{p}<$ 0.05 ) in serum concentrations for total protein, globulin, albumin/globulin ratio (A:G), creatinine, urea, phosphorus, calcium/phosphorus ratio (Ca:P), AST, and GGT between Senepol calves and crossbred Holstein x Gir calves, but no significant differences in serum concentrations were observed between male and female calves for either breed $(p>0.05)$. It was concluded that the serum biochemistry profile of newborn Senepol and crossbred Holstein x Gir calves was affected by differences in colostrum intake management and breed characteristics. Also, no differences in blood parameters were observed between male and female calves.
\end{abstract}

Key words: Serum biochemistry. Bovine. Colostrum.

\footnotetext{
${ }^{1}$ Discentes de Mestrado, Programa de Pós Graduação em Ciências Veterinárias, Universidade Federal de Uberlândia, UFU, Uberlândia, MG, Brasil. E-mail: lara_reisgomes@yahoo.com.br; renatavetufu@gmail.com; rafaelrocha62@yahoo.com.br

${ }^{2}$ Residente, Programa de Residência Üniprofissional em Medicina Veterinária, UFU, Uberlândia, MG, Brasil. E-mail: amanda_ bizare@hotmail.com

${ }^{3}$ Médico Veterinário, Faculdade de Medicina Veterinária, UFU, Uberlândia, MG, Brasil. E-mail: jgknychala@hotmail.com

${ }^{4}$ Discente de Doutorado, Programa de Pós-Graduação em Ciências Veterinárias, UFU, Uberlândia, MG, Brasil. E-mail: chrisresende@hotmail.com

${ }^{5}$ Prof. Dr., Faculdade de Matemática, UFU, Uberlândia, MG, Brasil. E-mail: ecg.ufu.br

${ }^{6}$ Prof. Dr., de Patologia Clínica Veterinária, Faculdade de Medicina Veterinária, UFU, Uberlândia, MG, Brasil. E-mail: antoniomundim@ufu.br

* Author for correspondence
} 


\title{
Resumo
}

\begin{abstract}
Objetivou-se avaliar as variações fisiológicas no perfil bioquímico sérico de bezerros neonatos da raça Senepol e mestiços Holandês x Gir de três a cinco dias idade, no município de Uberlândia, MG, e confrontar os valores entre as raças e sexos. Foram avaliados 168 bezerros neonatos, sendo 80 da raça Senepol (28 fêmeas e 52 machos) e 88 mestiços Holandês x Gir (49 fêmeas e 39 machos). Coletaram-se cinco mililitros de sangue, por venopunção da jugular externa, em tubos estéreis sem anticoagulante, para obtenção do soro. Foram determinadas as concentrações séricas de proteínas totais, albumina, creatinina, ureia, colesterol total, triglicérides, cálcio e fósforo; e as atividades de alanina aminotransferase (ALT), aspartato aminotransferase (AST), fosfatase alcalina e gama glutamiltransferase (GGT), em analisador automático multicanal. Confrontados os valores dos parâmetros avaliados entre a raça Senepol e os mestiços Holandês x Gir, as proteínas totais, globulinas, relação albumina e globulinas (A:G), creatinina, ureia, fósforo, relação cálcio e fósforo $(\mathrm{Ca}: \mathrm{P}), \mathrm{AST}$ e GGT apresentaram diferença $(\mathrm{p}<0,05)$, não se observando influência do sexo dentro de cada raça $(p>0,05)$. Conclui-se que a diferença no manejo de ingestão de colostro e fatores inerentes à raça influenciam no perfil bioquímico sérico de bezerros neonatos e não há diferença nos valores dos parâmetros estudados para machos e fêmeas.
\end{abstract}

Palavras-chave: Bioquímica sérica. Bovinos. Colostro.

Diseases of newborn calves are a major cause of economic loss in livestock production (PICCIONE et al., 2008), and minimizing neonatal mortality is critical for the success of animal management programs (PEKCAN et al., 2013). The neonatal period is characterized by a high susceptibility to disease, especially diarrhea and respiratory diseases. This period is also marked by rapid and intense changes in the serum chemistry profile of calves (PEKCAN et al., 2013). Colostrum feeding in calves is essential for disease protection and survival in the first few days of life and is considered the single most important management factor in determining health and survival of the neonatal calf. Inadequate colostrum intake may lead to starvation and increased susceptibility to infection and has significant effects on calf mortality and morbidity (PEKCAN et al., 2013).

The clinical evaluation of newborn calves for identification of adequate organic adaptation and presence of diseases often requires not only a physical examination, but also the use of complementary laboratory tests such as serum biochemical tests for analyzing the functional status of various organs. Moreover, a proper understanding of the physiological events that occur during the period of adaptation to extrauterine life is required for the interpretation of clinical signs and laboratory tests, to adequately treat and control morbid events, and to minimize economic losses (MOHRI et al., 2007).

Inadequate colostrum intake can have a significant impact on beef and dairy production. Given the importance of livestock farming in Brazil, colostrum feeding and management practices should include providing individual attention and care for calves immediately following birth, which led us to conduct this study.

Determining the serum chemistry profile of newborn Senepol and crossbred Holstein x Gir calves is crucial for the proper interpretation of results in sick animals and represents a valuable diagnostic tool in assessing failure of passive transfer (FPT) of immunity, the functioning of various organ systems, and the general clinical condition of animals. This study aimed to evaluate the physiological variations in the serum biochemical profile of neonate (3-5 days old) Senepol and crossbreed Holstein x Gir calves in Uberlândia, state of Minas Gerais, Brazil, and to compare values between breeds and sexes.

This study was previously approved by the Ethics Committee on Animal Use (CEUA) at Universidade Federal de Uberlândia (UFU) under 
protocol number 123/12. In total, 168 healthy eutocic Senepol ( $\mathrm{n}=80,28$ females and 52 males) and crossbred Holstein $\mathrm{x}$ Gir $(\mathrm{n}=88,49$ females and 39 males) calves aged 3-5 days were selected from four farms in Uberlândia, Minas Gerais. Senepol calves were born from embryo transfer to crossbred recipient dams at first or second calving, were individually monitored to ensure that colostrum was consumed within the first six hours after birth, and were left with dams during the experimental period. Crossbred Holstein x Gir calves were born from artificial insemination of cows with various genetic compositions and different calving orders. Calves were separated from dams after calving and kept in collective pens where they were separately fed 5-6 $L$ of their dam's recently milked colostrum within the first six hours of life and twice a day during the experimental period using a nipple bottle.

For each animal, approximately $5 \mathrm{~mL}$ of blood was collected by jugular venipuncture into a sterile tube without anticoagulant to obtain serum between three and five days postpartum. After collection, samples were stored in thermal boxes and sent to the Veterinary Clinical Laboratory at Universidade Federal de Uberlândia (UFU), where they were centrifuged at $720 \times \mathrm{g}$ for $5 \mathrm{~min}$. Next, serum aliquots were transferred into Eppendorf tubes and stored at $-20{ }^{\circ} \mathrm{C}$ for a maximum of $72 \mathrm{~h}$ until processing.

For each sample, the serum concentrations of total protein (biuret method), albumin (bromocresol green method), creatinine (alkaline picrate method), urea (UV enzymatic kinetic method), total cholesterol (Trinder enzymatic kinetic method), triglycerides (enzymatic kinetic method), calcium (cresolphthalein complexone [CPC] method), and phosphorus (UV kinetic method); and the activities of alanine aminotransferase (ALT) (IFCC UV kinetic method), aspartate aminotransferase (AST) (IFCC UV kinetic method), alkaline phosphatase (ALP) (optimized kinetic method), and gamma-glutamyl transferase (GGT) (modified Szasz method) were determined on a ChemWell automated multichannel analyzer (Awareness Technology Inc., Palm City,
FL, USA) using commercially available kits (Labtest Diagnostica ${ }^{\circledR}$, Lagoa Santa, MG, Brazil). The analyzer was previously calibrated with calibra $\mathrm{H}$ reagent and qualitrol $\mathrm{H}$ universal control serum (both Labtest Diagnostica ${ }^{\circledR)}$. Globulin levels were calculated from the difference between total protein and albumin concentrations, whereas A:G and $\mathrm{Ca}: \mathrm{P}$ represent the albumin/globulin and calcium/ phosphorus ratios, respectively.

The experiment was arranged in a randomized design with a $2 \times 2$ factorial structure (two breeds $\mathrm{x}$ two sexes) totaling four treatments. Data were analyzed using analysis of variance (ANOVA) for normally distributed variables with homogeneous variances, followed by the Tukey's test for comparisons of means between breeds and sexes, whereas non-parametric variables were analyzed using the Kruskal-Wallis test for comparisons of breeds and sexes. Differences were considered significant at $\mathrm{p}<0.05$. All analyses were performed using Action software (PORTAL ACTION, 2013).

There were significant differences $(\mathrm{p}<0.05)$ in serum concentrations for total protein, globulin, $\mathrm{A}: \mathrm{G}$, creatinine, urea, phosphorus, Ca:P, AST, and GGT between Senepol calves and crossbred Holstein x Gir calves (Table 1), but no significant differences in serum levels were observed between male and female calves for either breed $(p>0.05$, data not shown).

The analysis of blood biochemical indicators is a fast and reliable method for the evaluation of animal health. The concentrations of various blood constituents in calves change dramatically with age, particularly during the first week of life (MOHAMMAD, 2009). Thus, determining normal clinical values for biochemical constituents of blood may contribute to proper interpretation of laboratory results, early and accurate diagnosis, and help reduce neonatal mortality (HEROSIMCZYK et al., 2011).

The significantly higher levels of total protein and globulins in Senepol compared to 
Holstein x Gir crossbred calves may have been caused by a higher concentration of colostral immunoglobulins (RENGIFO et al., 2010). The high serum globulin levels resulted in low A:G ratios, but passive transfer of immunity was adequate in the two breeds, as shown by the high globulin levels.
Colostrum IgG concentrations are usually higher in taurine beef breeds than in dairy cattle breeds (COSTA et al., 2008). According to Soares Filho et al. (2001), adequate transfer of immunoglobulins can be achieved through natural suckling in beef breeds, as was observed in Senepol calves in our study.

Table 1. Serum biochemical parameters (mean \pm SD) in Senepol and crossbred Holstein $x$ Gir calves aged 3-5 days from Uberlândia, Minas Gerais, Brazil.

\begin{tabular}{lcc}
\hline Biochemical parameter & $\begin{array}{c}\text { Senepol } \\
(\mathbf{n = 8 0})\end{array}$ & $\begin{array}{c}\text { Crossbred Holstein x Gir } \\
(\mathbf{n = 8 8})\end{array}$ \\
\hline Total protein $\left(\mathrm{g} \mathrm{dL}^{-1}\right)$ & $9.49 \pm 1.53 \mathrm{a}^{*}$ & $8.61 \pm 1.56 \mathrm{~b}^{*}$ \\
Albumin $\left(\mathrm{g} \mathrm{dL}^{-1}\right)$ & $2.31 \pm 0.53 \mathrm{a}$ & $2.49 \pm 0.50 \mathrm{a}$ \\
Globulin $\left(\mathrm{g} \mathrm{dL}^{-1}\right)$ & $7.18 \pm 1.55 \mathrm{a}^{*}$ & $6.12 \pm 1.47 \mathrm{~b}^{*}$ \\
A:G ratio & $0.34 \pm 0.13 \mathrm{~b}$ & $0.43 \pm 0.15 \mathrm{a}$ \\
Creatinine $\left(\mathrm{mg} \mathrm{dL}^{-1}\right)$ & $0.98 \pm 0.35 \mathrm{a}^{*}$ & $0.81 \pm 0.27 \mathrm{~b}^{*}$ \\
Urea $\left(\mathrm{mg} \mathrm{dL}^{-1}\right)$ & $27.71 \pm 13.09 \mathrm{a}$ & $21.06 \pm 13.73 \mathrm{~b}$ \\
Total cholesterol $\left(\mathrm{mg} \mathrm{dL}^{-1}\right)$ & $49.59 \pm 17.33 \mathrm{a}^{*}$ & $51.84 \pm 17.02 \mathrm{a}^{*}$ \\
Triglycerides $\left(\mathrm{mg} \mathrm{dL}^{-1}\right)$ & $32.88 \pm 21.06 \mathrm{a}$ & $31.27 \pm 17.55 \mathrm{a}$ \\
Calcium $\left(\mathrm{mg} \mathrm{dL}^{-1}\right)$ & $10.97 \pm 0.97 \mathrm{a}$ & $10.68 \pm 0.87 \mathrm{a}$ \\
Phosphorus $\left(\mathrm{mg} \mathrm{dL}^{-1}\right)$ & $10.85 \pm 2.85 \mathrm{a}$ & $9.59 \pm 2.19 \mathrm{~b}$ \\
Ca:P ratio & $1.06 \pm 0.24 \mathrm{~b}$ & $1.16 \pm 0.22 \mathrm{a}$ \\
ALT $\left(\mathrm{U} \mathrm{L} \mathrm{L}^{-1}\right)$ & $22.30 \pm 22.72 \mathrm{a}$ & $20.02 \pm 17.84 \mathrm{a}$ \\
AST $\left(\mathrm{U} \mathrm{L} \mathrm{L}^{-1}\right)$ & $49.44 \pm 22.64 \mathrm{a}$ & $38.28 \pm 16.54 \mathrm{~b}$ \\
ALP $\left(\mathrm{U} \mathrm{L}^{-1}\right)$ & $351.99 \pm 215.50 \mathrm{a}$ & $303.82 \pm 110.52 \mathrm{a}$ \\
GGT $\left(\mathrm{U} \mathrm{L}^{-1}\right)$ & $1,208.24 \pm 1,087.45 \mathrm{a}$ & $401.49 \pm 345.48 \mathrm{~b}$ \\
\hline
\end{tabular}

ALT: alanine aminotransferase; AST: aspartate aminotransferase; ALP: alkaline phosphatase; and GGT: gamma-glutamyl transferase. Different letters in rows indicate significant differences between breeds $(\mathrm{p}<0.05)$.

*Tukey's test; all others: Kruskal-Wallis test.

Because colostral immunoglobulin concentrations are generally higher in beef breed cows such as Senepol than in dairy cows, the passive transfer of immunity may be more efficient in Senepol calves, and consumption of smaller volumes of colostrum may provide adequate amounts of immunoglobulins required for the passive transfer of immunity (BESSER et al., 1991), compared to calves with dairy aptitude such as crossbred Holstein x Gir calves (SOARES FILHO et al., 2001). Moreover, calf serum immunoglobulin concentrations are more dependent on individual factors (i.e., absorption failure) and colostrum management than on colostrum quality (VAZ et al., 2004).

The higher creatinine and AST values in Senepol calves compared to Holstein x Gir calves can be attributed to their greater muscle mass and increased metabolism of creatine and phosphocreatine, which are energy storage forms in skeletal muscle. Creatinine and AST levels correlate with muscle mass, and variations in serum creatinine levels are the result of dynamic changes in muscle mass (MOHRI et al., 2007). 
Serum urea levels are a major indicator of animal protein metabolism (BENESI et al., 2005). In fact, even though urea levels were significantly higher in Senepol calves than in crossbred Holstein x Gir calves, the difference was small and could be attributed to a slight increase in protein metabolism in Senepol calves, because urea levels were within the physiological range for the species in the two breeds (KANEKO et al., 2008).

Colostrum is rich in minerals (phosphorus) and in the enzyme GGT (GOMES et al., 2010; ROCHA et al., 2012). Thus, the higher serum phosphorus and GGT levels observed in Senepol calves in our study may be explained by differences in the concentration of ingested colostrum between Senepol and Holstein x Gir calves. In addition, because of the higher phosphorus levels, the Ca:P ratio was significantly smaller in Senepol calves than in Holstein $x$ Gir calves.
The higher serum phosphorus levels observed in Senepol calves compared to Holstein x Gir calves may be due to the early maturation and rapid growth of Senepol cattle, which likely result in higher growth hormone (GH) levels and greater phosphorus requirements for bone growth (KANEKO et al., 2008).

Serum GGT levels were three times higher in Senepol calves than in crossbred Holstein $\mathrm{x}$ Gir calves (Figure 1). Because the volume of colostrum consumed was not quantified, this result indicates that the concentration of GGT in colostrum ingested by Senepol calves was higher than it was for Holstein x Gir calves. Similarly, significant differences in serum GGT activity were observed between newborn calves from Nellore beef cattle and Holstein dairy cattle (FEITOSA et al., 2010). In fact, serum GGT activity has been considered a reliable indicator of passive transfer of immunity status in newborn calves (GOMES et al., 2010; PEKCAN et al., 2013).

Figure 1. Serum gamma-glutamyl transferase (GGT) levels in Senepol and crossbred Holstein x Gir calves aged 3-5 days from Uberlândia, Minas Gerais, Brazil.

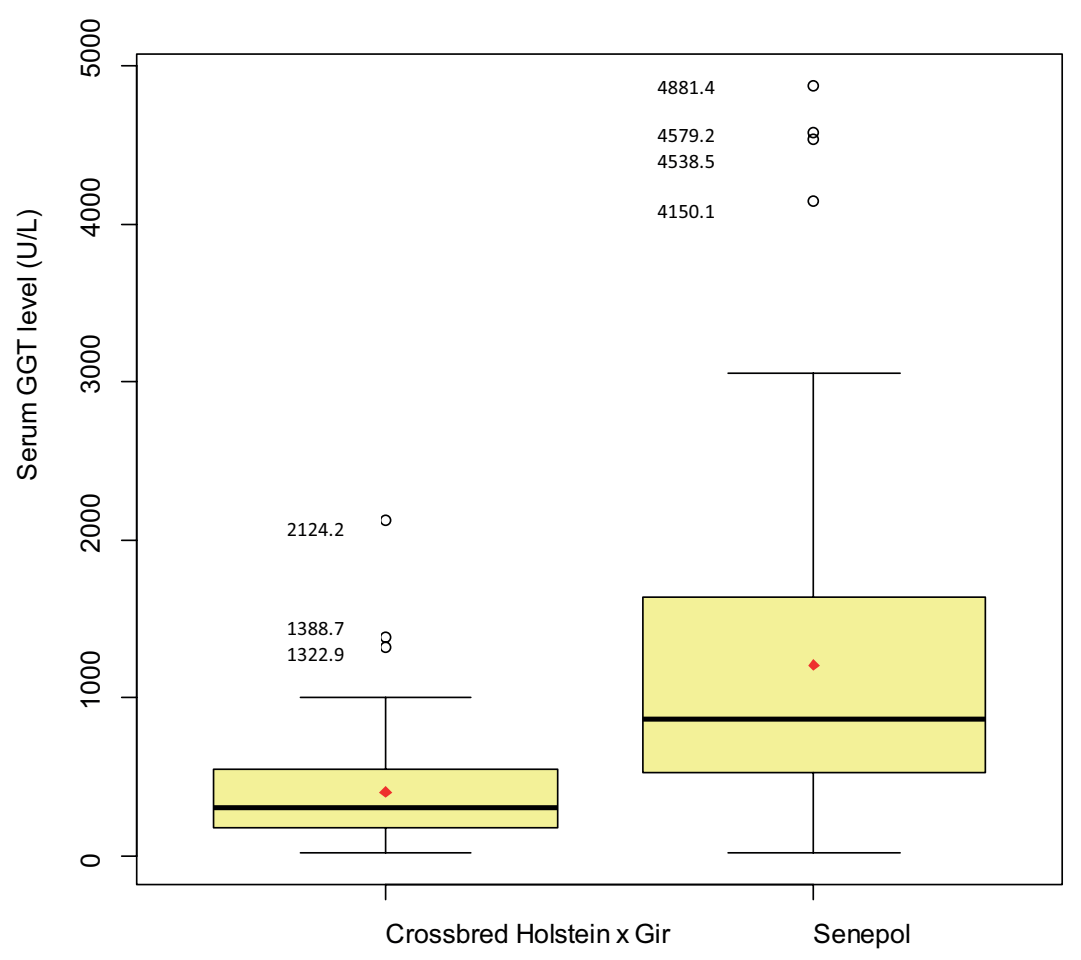


Due to the scarcity of studies on the serum chemistry profile of newborn calves, particularly from Senepol cattle, the results of this study may contribute to improve neonatal calf assessment and serve as a basis for future research on neonatal calf health.

In conclusion, the serum chemistry profile of newborn Senepol and Holstein x Gir calves was affected by differences in colostrum intake management and breed characteristics. No differences in blood parameters were observed between male and female calves.

\section{Acknowledgments}

We are grateful to the cattle owners who kindly allowed the blood samples collection from their animals.

\section{References}

PORTAL ACTION. Estatcamp - Consultoria estatística e qualidade, São Carlos, SP, Brasil 2013. Disponível em: $<$ http://www.portalaction.com.br $>$. Acesso em: 04 set. 2013.

BENESI, F. J.; COELHO, C. S.; LEAL, M. L. R.; SAKATA, R. M.; LISBÔA, J. A. Parâmetros bioquímicos para avaliação da função renal e do equilíbrio hidroeletrolítico em bezerras sadias, da raça Holandesa, no primeiro mês de vida. Brazilian Journal of Veterinary Research and Animal Science, São Paulo, v. 42, n. 4, p. 291-298, 2005.

BESSER, T. E.; GAY, C. C.; PRITCHETT, L. Comparison of three methods of feeding colostrum to dairy calves. Journal of the American Veterinary Medical Association, Schaumburg, v. 198, n. 3, p. 419-422, 1991.

COSTA, M. C.; FLAIBAN, K. K. M. C.; CONEGLIAN, M. M.; FEITOSA, F. L. F.; BALARIN, M. R. S.; LISBÔA, J. A. N. Transferência de imunidade passive em bezerros das raças Nelore e Limousin e proteinograma sérico nos primeiros quatro meses de vida. Pesquisa Veterinária Brasileira, Rio de Janeiro, v. 28, n. 9, p. 410-416, 2008.

FEITOSA, F. L. F.; CAMARGO, D. G.; YANAKA, R.; MENDES, L. C. N.; PEIRÓ, J. R.; BOVINO, F.; LISBOA, J. A. N.; PERRI, S. H. V.; GASPARELLI, E. R. F. Índices de falha de transferência de imunidade passiva (FTIP) em bezerros holandeses e nelores, às 24 e 48 horas de vida: valores de proteína total, de gamaglobulina, de imunoglobulina $\mathrm{G}$ e da atividade sérica de gamaglutamiltransferase, para o diagnóstico de FTIP. Pesquisa Veterinária Brasileira, Rio de Janeiro, v. 30, n. 8, p. 696-704, 2010.

GOMES, V.; MADUREIRA, K. M.; BLAGITZ, M. G.; GALDINO, J.; VANTIM, G.; BENESI, F. J. Valores de referência e influência do fator etário sobre os parâmetros bioquímicos utilizados para avaliação da avaliação da função hepática de bubalinos hígidos da raça Murrah. Ars Veterinária, Jaboticabal, v. 26, n. 3, p. 128-131, 2010.

HEROSIMCZYK, A.; LEPCZYŃSKY, A.; DRATWACHALUPNIK, A.; KURPIŃSKA, A.; KLONOWSKA, A.; SKRZYPCZAK, W. F. Age-related changes of selected blood biochemical indicators in dairy calves during their first week of life. Folia Biologica, Kraków, v. 59, n. 1-2, p. 25-30, 2011.

KANEKO, J. J.; HARVEY, J. W.; BRUSS, M. L. Clinical biochemistry of domestic animals. $6^{\text {th }}$ ed. San Diego: Academic Press, 2008. 916 p.

MOHAMMAD, M. A. Mineral status in blood serum of newborn calves in Assiut Governorate. Beni-Suef Veterinary Medical Journal, Beni-Suef, v. 19, n. 1, p. 5156, 2009.

MOHRI, M.; SHAFIRI, K.; EIDI, S. Hematology and serum biochemistry of Holstein dairy calves: age related changes and comparison with blood composition in adults. Research in Veterinay Science, London, v. 83, n. 1, p. 30-39, 2007.

PEKCAN, M.; FIDANCI, U. R.; YUCEER, B.; OZBEYAZ, C. Estimation of passive immunity in newborn calves with routine clinical chemistry measurements. Ankara Üniversitesi Veteriner Fakültesi Dergisi, Ankara, v. 60, n. 2, p. 85-88, 2013.

PICCIONE, G.; BERTOLUCCI, C.; GIANNETTO, C.; GIUDICE, E. Clotting profiles in newborn Maltese kids during the first week of life. Journal Veterinary Diagnostic Investigation, Columbia, v. 20, n. 1, p. 114118, 2008.

RENGIFO, S. A.; SILVA, R. A.; BOTTEON, R. C. C. M.; BOTTEON, P. T. L. Hemograma e bioquímica sérica auxiliar em bezerros mestiços neonatos e ocorrência de enfermidades. Arquivos Brasileiros de Medicina Veterinária e Zootecnia, Belo Horizonte, v. 62, n. 4, p. 993-997, 2010.

ROCHA, T. G.; NOCITI, R. P.; SAMPAIO, A. A. M.; FAGLIARI, J. J. Passive immunity transfer and serum constituents of crossbred calves. Pesquisa Veterinária Brasileira, Rio de Janeiro, v. 32, n. 6, p. 515-522, 2012. 
SOARES FILHO, P. M.; BELÉM, P. A. D.; RIBEIRO JÚNIOR, J. I.; SALCEDO, J. H. P. Concentrações de imunoglobulinas $\mathrm{g}$ em colostro de vacas mestiças Holandês-Zebu. Ciência Rural, Santa Maria, v. 31, n. 6, p. 1033-1037, 2001.
VAZ, A. K.; FURTADO, A. C.; MARCA, A.; PATERNO, M. R. Qualidade do colostro bovino e transferência de imunidade aos bezerros recém-nascidos na Região de Lages, SC. Revista de Ciências Agroveterinárias, Lages, v. 3, n. 2, p. 116-120, 2004. 
